http:/ /dx.doi.org/10.1590/0104-07072017006800015

\title{
URINARY INCONTINENCE IN ELDERLY PEOPLE: CARE PRACTICES AND CARE PROPOSAL IN PRIMARY HEALTH CARE ${ }^{1}$
}

\author{
Andrelise Viana Rosa Tomasi², Silvia Maria Azevedo dos Santos³, Gesilani \\ Júlia da Silva Honório ${ }^{4}$, Melissa Orlandi Honório Locks ${ }^{5}$
}

${ }^{1}$ Paper extracted from the thesis - Health promotion of elderly women with urinary incontinence: interdisciplinary care, presented
to the Programa de Pós-graduação em Enfemragem (PEN), Universidade Federal de Santa Catarina (UFSC), in 2015.
${ }^{2}$ Doctoral student. PEN/UFSC. Professor, Centro Universitário Estácio de Sá de Santa Catarina. Florianópolis, Santa Catarina, Brazil.
E-mail: andrelisev@gmail.com
${ }^{3}$ Ph.D. in Nursing. Professor, Nursing Department, PEN/UFSC. Florianópolis, Santa Catarina, Brazil. E-mail: silvia.
azevedo@ufsc.br
${ }^{4}$ Ph.D. in Nursing. Professor, Physiotherapy Department, Universidade do Estado de Santa Catarina. Florianópolis, Santa Catarina,
Brazil E-mail: gesilani@hotmail.com
${ }^{5}$ Ph.D. in Nursing. Professor, Nursing Department, PEN/UFSC. Florianópolis, Santa Catarina, Brazil. E-mail: melhonorio@hotmail.com

\section{ABSTRACT}

Objective: identify the knowledge and care practices concerning urinary incontinence in elderly women and develop a care proposal for these women for the purpose of health promotion in Primary Health Care.

Method: a qualitative, convergent care research was undertaken. The data were collected between August and October 2014 through semistructured interviews and thematic workshops with 14 physiotherapists and ten nurses. The analysis involved apprehension, synthesis, theorization and transference processes, revealing two thematic axes: the professionals' perception of urinary incontinence in elderly women; and the conception of a care proposal for elderly women with urinary incontinence.

Results: the professionals' limited knowledge of urinary incontinence was verified, as well as the lack of information on the possible orientations for self-care concerning the urinary symptoms.

Conclusion: training actions should be implemented for these professionals with a view to health promotion for self-care.

DESCRIPTORS: Elderly. Urinary incontinence. Physiotherapy. Nursing. Primary health care.

\section{INCONTINÊNCIA URINÁRIA EM IDOSAS: PRÁTICAS ASSISTENCIAIS E PROPOSTA DE CUIDADO EM ÂMBITO DA ATENÇÃO PRIMÁRIA DE SAÚDE}

\section{RESUMO}

Objetivo: identificar o conhecimento e as práticas assistenciais sobre a incontinência urinária em mulheres idosas e desenvolver proposta de cuidado a essas mulheres para a promoção da saúde no âmbito da atenção primária de saúde.

Método: pesquisa qualitativa, do tipo convergente-assistencial, cujos dados foram coletados entre agosto e outubro/2014, através de entrevistas semiestruturadas e oficinas temáticas com 14 fisioterapeutas e dez enfermeiros. A análise envolveu processos de apreensão, síntese, teorização e transferência, fazendo emergir dois eixos temáticos: percepção dos profissionais acerca da incontinência urinária em mulheres idosas; e a concepção de uma proposta de cuidado à mulher idosa com incontinência urinária.

Resultados: constatou-se o pouco conhecimento dos profissionais acerca da incontinência urinária, bem como a falta de informação em relação às possibilidades de orientações para o autocuidado a respeito dos sintomas urinários.

Conclusão: recomenda-se implementar ações de capacitação com estes profissionais, com vistas à promoção da saúde para o autocuidado. DESCRITORES: Idoso. Incontinência urinária. Fisioterapia. Enfermagem. Atenção primária à saúde. 


\title{
INCONTINENCIA URINARIA EN MUJERES ANCIANAS: PRÁCTICAS DE CUIDADO Y PROPUESTA DE CUIDADOS EN EL CONTEXTO DE LA ATENCIÓN PRIMARIA SALUD
}

\begin{abstract}
Objetivo: identificar los conocimientos y prácticas de cuidado de la incontinencia urinaria en mujeres ancianas y desarrollar propuesta de la atención a estas mujeres para promover la salud en el contexto de la atención primaria de salud.

Método: investigación cualitativa, el tipo de investigación atención convergente, cuyos datos fueron recolectados entre agosto y octubre / 2014 a través de entrevistas semiestructuradas y talleres temáticos con 14 fisioterapeutas y 10 enfermeras. El análisis incluyó la confiscación de los procesos, la síntesis, teorización y transferencia, dando lugar a dos temas principales: la percepción de los profesionales sobre la incontinencia urinaria en mujeres de edad avanzada; y el diseño de una atención propuesta a anciana con incontinencia urinaria.

Resultados: se encontró el poco conocimiento de los profesionales acerca de la incontinencia urinaria, así como la falta de información sobre las posibilidades de directrices para el cuidado personal respecto a los síntomas urinarios.

Conclusión: se recomienda llevar a cabo actividades de formación con estos profesionales, con el objetivo de promoción de la salud para el autocuidado.
\end{abstract}

DESCRIPTORES: Ancianos. Incontinencia urinaria. Fisioterapia. Enfermería. Atención primaria de salud.

\section{INTRODUCTION}

Human aging entails countless challenges for care, deriving from existing chronic pathologies. These challenges include Urinary Incontinence (UI), which can imply problems for healthy aging with quality of life.

The urine losses mainly affect women, of different age ranges, but with a higher prevalence in elderly women, but with a higher prevalence in elderly women, which can range from $26.2 \%$ to $37.9 \%$, against $6.2 \%$ to $15.5 \%$ in men. ${ }^{1-3}$ The high prevalence in women can be due to the physical-functional transformations that take place in the course of the aging process, such as the climacteric period and the menopause. Unfortunately, in Brazil, we do not have clearer statistical data in this respect yet, as epidemiological studies are scarce. This is due to the fact that most studies are developed using small or punctual samples, besides using distinct methods.

Another aspect that stands out is the fact that most elderly women underestimate or omit the UI symptoms since the initial phase, which can entail emotional, social and physical losses. ${ }^{4}$ Many of them see this situation as something normal for their age, that is, the symptoms of UI are naturalized, living with this without seeking professional help. ${ }^{5}$ It is highlighted that the non-reporting of this dysfunction also happens due to the feeling of shame and lack of knowledge on the existence of treatment to minimize or cure the symptoms. ${ }^{6}$

Some studies have demonstrated the occurrence of UI associated with advanced age, the obstetric history and parity, with gynecological surgeries, the menopause, Systemic Arterial Hypertension (SAH), Diabetes Mellitus (DM), obesity, smoking, alcohol, intake of fluids with caffeine and sedentariness. ${ }^{7-12}$
Based on these risk factors, it is considered that some behaviors can change in some women, in principle without a background clinical diagnosis of UI, which can develop secondarily to the treatment of other diseases. Therefore, a precise investigation of the risk factors is needed in order to minimize the symptoms of UI. ${ }^{13-14}$

Recycling and/or training can contribute to a more qualified care practice for elderly people. In the multidisciplinary context, since Primary Health Care (PHC), the professionals can develop interventions for the purpose of health promotion and self-care of elderly women with UI. Therefore, it is fundamental for the professionals to deliver care that permits a better understanding and knowledge among the elderly with regard to the symptoms and risk factors of UI. That will allow the women to talk about this theme and seek treatment for the control of this dysfunction, so that they can accept and cope with the challenges the UI provokes. ${ }^{15}$

The questions presented here demonstrate the need to deepen the care aspects with regard to the elderly population. Hence, the objective in this study was to identify the knowledge and care practices for Urinary Incontinence in elderly women and develop care proposals for elderly women with urinary incontinence for the purpose of health promotion in the primary health care context.

\section{METHOD}

A qualitative (Pesquisa Convergente Assistencial$P C D){ }^{16}$ was undertaken, using Health Promotion as a reference framework. The guidelines of the National Policy of Health Promotion remit to the principles and guidelines of the Unified Health System (SUS), in which the construct of cross-sectional articulation grants visibility to the factors that put the health of 
the population at risk and to the differences in terms of needs, territories and cultures. These guidelines are intended to create mechanisms that reduce the situations of vulnerability, defend the equity and incorporate participation and social control into public policy management. The public actions should go beyond the idea of cure and rehabilitation. ${ }^{17}$

The research data were collected between August and October/2014 through the semistructured interview and thematic workshop techniques, involving 14 physiotherapists and ten nurses, at a Health District of a capital in the South of Brazil.

To choose the participants, the following inclusion criteria were observed for the physiotherapists: being a physiotherapist from the city of Florianópolis, independently of the Health District, and having worked in care for at least four months. The inclusion criteria for the nurses were: being a nurse from the Central Health District and having worked in care for at least four months. It is estimated that, based on the length of this experience, the professionals are already familiar with the system and the community.

The interviews were held at the participants' workplace after making an appointment. At the moment of the interview, the informants were asked to read and sign two copies of the Free and Informed Consent Form (FICF), one copy for the researcher and another for the participant. To preserve the secrecy and anonymity, all participants were identified by the letter " $\mathrm{P}$ " for physiotherapist or " $\mathrm{N}$ " for nurse, followed by an Arabic numeral according to the order in which they entered the study.

After the interviews, three thematic workshops were held at 30-day intervals. In the first workshop, some important data on UI were discussed, such as: anatomy and physiology of continence, types of UI, prevalence and risk factors. During the second workshop, the conservative treatment physiotherapy and nursing can provide to elderly women with UI was discussed in theory and practice. Finally, in the third workshop, the previous meetings were reviewed, closing off with the construction of the educative material. We used various strategies to implement the workshops, such as: didactical texts, updated articles, illustrations, exercises of muscle strengthening techniques, among others.

The data analysis followed the qualitative analysis steps suggested by CCR: apprehension (collection of information from the individual semistructured interviews and thematic workshops, which were organized and registered in the field diary to permit the apprehension of their meaning); synthesis (the information found in the apprehension phase were subjectively analyzed, looking for associations and variations in this information in order to code it); theorization (the phase in the value of the information surveyed was discovered in the synthesis process, in line with the theoretical framework); and transfer (end of the analytic process, focused on giving meaning to findings and discoveries, aiming to contextualize them in similar situations in order to socialize the results). ${ }^{16}$ Through the reading and rereading of the texts produced from the interview and workshop transcripts, the units of meaning emerged that originated the coding process. To achieve one of the research objectives, during the final thematic workshop, the participants elaborated educative material to facilitate the communication between the professionals and the elderly women.

The research complied with National Health Council Resolution 466/2012. ${ }^{18}$ It was submitted to the Ethics Committee for Research involving Human Beings of Universidade Federal de Santa Catarina (UFSC), CAAE: 33149114.5.0000.0121, and approved under Opinion 766.045.

\section{RESULTS AND DISCUSSION}

Study involving 24 participants, 14 of whom were physiotherapy professionals and ten nursing professionals. What gender is concerned, 11 physiotherapists were female and three male, and the nurses were all female. The length of experience in the municipal government ranged between four months and 17 years.

After the data analysis process, two thematic axes were revealed, which are: "Perception of professionals on urinary incontinence in elderly women"; and "The conception of a care proposal for elderly women with urinary incontinence". Each of these axes rests on categories that are intended to answer the research objectives.

\section{Perception of the professionals on urinary incontinence in elderly women}

This thematic axis demonstrates what was verified with regard to the investigated professionals' perception of UI in elderly women. It rests on the following categories: "Restricted/limited knowledge on the risk factors for UI", "The omission of elderly women to talk about UI", and "Limited knowledge of care practices for women with UI". These data were collected through interviews.

In the course of this study, it could be observed that the physiotherapists and nurses presented re- 
stricted/limited knowledge on the risk factors for UI, as they appointed only some risk factors that can favor the occurrence of UI in elderly women. This condition can be observed in the following statements: [...] the hormonal aspect in women, which affects a loss of control, the aging aspect of the whole musculoskeletal system, which leads to muscle weakness, atrophy [...] (P8). [...] if she's in the climacteric period or menopause, then it's normal [...], but that is related to the physiological process (N2).

These testimonies evidence that apparently diffuse knowledge existed, but no reports were found on the importance of advising the attended users with regards to care, such as: healthy eating habits, correct medication use, chronic disease control, measures to prevent constipation, avoid smoking and alcohol, among others. It is known that these risk factors could prevent and/or minimize the symptoms. In addition, if the elderly women were informed, they could incorporate this care into their self-care routine.

Another aspect that makes it difficult to identify patients with urine loss is the aspect of "elderly women's omission to talk about UI", such as taboo and shame, which prevents them from talking about the theme. During the interviews, the professionals also discussed this theme, proposing a reflection on this situation, as can be verified in the following testimonies: [...] they have a bigger blockade, as if it were a taboo, it was a prohibited part (P12). [...] I notice that there's still great taboo, it has to be well conducted, with the words well placed (P9).

The professionals in this study perceived the delicateness needed to investigate the presence and frequency of the UI. Therefore, the professionals' training is considered one of the routes for them to be able to discuss this theme naturally, making the patient feel at easy to talk about this dysfunction.

For the women, the UI is considered a taboo, probably due to the constraint this condition imposes, which prevents them from seeking treatment. In a study involving 142 interviewees, they perceived that, despite the high prevalence of UI, $60.6 \%$ considered it was a taboo to talk about this theme. ${ }^{19}$

In that sense, it is evidenced that if, on the one hand, there is still a taboo for the patient to talk about the theme, on the other, the health professionals also need to overcome their stigmas. This can be done by strengthening bonds with the users, which can favor a calm and open discussion on this theme. Thus, the elderly women will have further access to the information and can understand that the UI is not part of the natural aging process, that conservative treatments are available for this dysfunction.
Together with the taboo, there was shame, in a study involving 305 women between 40 and 65 years of age, to seek treatment for the UI symptoms. A more relevant level of internalized shame was perceived with regard to social isolation and social rejection. The attitudes regarding the treatment for UI were negative for these women studied. ${ }^{20}$

In an investigation to discover the meaning of having UI and being incontinent, other studies perceived that the feeling of shame interferes in social life and well-being and can be associated with psychological and emotional problems, such as: fear, nervousness and depression. ${ }^{21-22}$

With respect to elderly women, both the orientations and management of UI should be done in a sensitive and respectful manner, in order to help them to express their feelings and doubts, which will favor their compliance with the proposed treatment. To assume this position, the professionals need to be knowledgeable about this dysfunction and treatment possibilities. Hence, in the next category, "the limited knowledge about care practices for women with UI will be discussed", as observed in the following statements:[...] the relation I see is the non-information, it's a thing of old people, this problem that leads to these biopsychosocial disorders, which is important in women and could largely be minimized (P2). The women do not question much, because they think that it cannot be revered, generally they complain when the problem is already quite present (N10). I think it's a bit that the users do not know that there is treatment, they do not know that, they do not take this complain to the health center (P11).

In these reports, it is verified that the difficulties to discuss UI relate to the patients. Nevertheless, the professionals also expect the elderly to complain spontaneously, which may not be due to taboo, shame and lack of knowledge that UI is a health problem.

A study was intended to assess the prevalence, communication between patient and physician and health treatment associated with UI and vulnerably elderly through the Medicare Health Outcomes Survey in the United States between 2006 and 2012. It was verified that $311,524(37.55 \%)$ of the individuals over 65 years of age or older reported problems with UI. About $48-50 \%$ of them had small problems and $77-79 \%$ a big problem to inform their physicians about the UI problem. Nevertheless, $30 \%$ received some treatment in the group with a small UI problem, with small changes over the years. In the group with a big problem, about $50 \%$ received some kind of treatment. ${ }^{23}$ 
In another study to identify the barriers in the search for treatment, involving 141 women with UI between 47 and 81 years of age, it was verified that the majority $(70.5 \%)$ mentioned to the doctor that they thought that the involuntary urinary losses were part of the aging process and that they could not be cured. In addition, $11.5 \%$ of the women investigated indicated that various physicians confirmed this conviction on the relation between UI and aging, underrating treatment possibilities. ${ }^{24}$

In a study of 313 menopausal women, then, it was identified that $27.2 \%$ sought medical help for the urinary symptoms, and many women declared that the UI was neglected in the care delivered by the health team. ${ }^{25}$

In the course of this study, we applied another data collection technique: the thematic workshops. During these, the physiotherapists and nurses received further information on the UI to improve the care for incontinent elderly women. Based on the analysis and interpretation of the data produced in the workshops, another thematic axis was reached regarding the professionals' reflections on UI in elderly women, as discussed next.

\section{The conception of a care proposal for elderly women with urinary incontinence}

To devise care possibilities, this thematic axis rests on the following categories: "General self-care orientations", "Experiencing pelvic floor exercises" and "The synthesis of information for self-care in UI and old age".

The category "general orientations for selfcare" emerged during the first thematic workshop of this study. After a presentation by the researcher on the anatomy and physiology of UI, the existing types of UI, the risk factors, the foods that irritate the bladder and the prevalence rate of this problem in elderly women, a reflection took place with the professionals on some care that can be taken since PHC. Some of these actions are presented in the following statements: the initial orientations we already provide as a form of prevention, involving regularly physical exercise, not holding the urine for long, we advise on exercising the holding of urine, in order to strengthen the muscles; we do not even have further experience to advise on other types of exercises (Nurses).

Through the reports of the nurses, it was noticed that they already worked on the prevention of UI and health promotion, when they advised on the importance of healthy life habits. Some nurses still mixed up the exercise orientations though, focusing only on exercises during the micturition, which is not the most effective way to strengthen the pelvic floor muscles.

This shortage was not found in our informants only. In a study developed to identify UI, the results were not that different. Out of 37 physicians and 19 nurses who participated in this investigation, seven nurses and three physicians did not know the signs and symptoms that should be investigated. ${ }^{26}$

In an experience report, based on professionals' perception at a health care, it was observed that, during a training session, they were able to identify the need for patient care and to develop strategies needed to advise on self-care. This report permitted a reflection on the role of the health service professionals' continuing training, as it allows them to recycle their knowledge for the users' demands, knowing how to identify and implement the care needed for individuals with UI. ${ }^{27}$

On the other hand, in our thematic workshops, we perceived that the physiotherapy professionals presented some more knowledge on UI, as observed in the following statements: [...] some breathing exercises, inspiring deeply and releasing through the mouth, contracting the pelvic floor. Care should be taken with the orientation, in fact, the bad advice the women do are the exercises during the micturition, that should be done, but not at that moment. There are many women who have no bodily awareness for us to say: 'contract the perineum', there are many women who do exactly the opposite (Physiotherapists).

These reports indicate the knowledge for the orientations and care with patients presenting symptoms of UI. If a multiprofessional approach were adopted, perhaps everyone could develop a better investigation to identify the types of UI, its severity and the possible orientations and treatment.

In a study, it was demonstrated that, with regard to the women's approach of UI, the nursing professionals investigated during different types of care, such as the oncotic cytology collection, during the prenatal consultation and during the welcoming. The physicians, then, approached the women during the routine medical and gynecological consultations. ${ }^{26}$

In a systematic literature review to identify nursing diagnoses in elderly women with UI, impaired cognition, constipation, urinary infection, restricted mobility, complete medication regimen, obesity, smoking and excessive substance use (caffeine) were highlighted as determinants. In addition, the consequences were evidenced, such as impaired sleep, anxiety, impaired health maintenance, depression, social isolation, fear, reduced fluid intake, 
reduced self-esteem, solitude and shame. The authors concluded that these diagnoses can facilitate the identification of the problem and the implementation of interventions focused on minimizing the symptoms in the different scenarios of health care practice. ${ }^{28}$

What the bodily awareness is concerned, the physiotherapy professionals can significantly collaborate in the treatment of UI through teaching and information on the appropriate use of the pelvic floor muscles. In a study involving ten women, the importance of these professionals was demonstrated in the awareness raising and learning about pelvic floor muscle contraction in women with UI. These study findings evidenced that $80 \%$ of the women indicated complete improvement and $20 \%$ partial improvement of the urinary symptoms through the functional training of the pelvic muscles, electrotherapy and orientations, by means of a leaflet with home exercises. ${ }^{29}$

Therefore, it is clear that the patients who perform the exercises under the supervision of a professional for orientation, giving commands in simple and understandable language, are able to significantly execute the correct contraction of the pelvic muscles. On the opposite, the women without appropriate bodily awareness to execute the exercises correctly can present a high incidence of treatment abandonment or dropout when they are not oriented correctly. ${ }^{30}$

Mainly in the context of elderly women, whose motor coordination is already impaired, the isolated contraction of the pelvic muscles is more difficult. That was evidenced in a study intended to assess the muscle strength of the pelvic floor muscles in 22 elderly women with UI through bidigital palpation and the quantification of perineal contractions by means of a perineometer. The findings demonstrated that, after the kinesiotherapeutic treatment through awareness raising exercises twice per month, during individual 30-minute sessions, totaling 12 sessions, a significant improvement in muscle strength, peak pressure and contraction time measured by the perineometer was observed. ${ }^{31}$

Therefore, the objective of the second thematic workshop in this study was to practice the pelvic muscle strengthening exercises, so that the professionals could incorporate them and feel more confident to instruct the elderly women with UI who seek PHC. Thus, another category emerged, "experiencing the pelvic flood exercises".

The statements below illustrate that some professionals presented difficulties to perform the pelvic exercises: I am unable to feel the perineum only in that position [laying down], but if I put my hand directly, I feel it [...]. It is difficult, but I think I was taking the wrong place [...]. I think the aspect of the exercises is easier for us to address, we should train more to be able to give these orientations (Nurses).

The above statements present the need for the health professionals to learn and correctly train the pelvic floor muscle strengthening exercises. Thus, they will be better equipped for care to allow the attended elderly women to include them in their selfcare. These orientations can be provided since PHC to improve and/or solve some symptoms many women experience, according to the statements below:

with the orientations seen here, in some cases, there is no need to forward for a consult with the gynecologist, nor for physiotherapy [...]. The ideal is to do the background filter [...] we can build it together, one of the objectives here is to sensitize, for us to be able to work more because, in many women, it is solved in a very simple manner (Physiotherapist).

After the first thematic workshops, it was demonstrated that many professionals presented neither the knowledge nor the experience needed to attend to elderly women with UI. In that sense, in the final workshop, the synthesis of information for care in UI was elaborated, which was finally consolidated as another category. During this workshop, the researcher took some case studies on the theme to present to the participants. They were divided in small groups and, after solving the study, it was highlighted that they found it feasible to perform this care in their professional reality in PHC. The result of this work is presented in Table 1, below:

- Nutritional orientation and physical exercise;

- Pelvic strengthening exercises;

- Involving the partner/family in care;

- Health education about the theme;

- Request micturition diary;

- Orientation on fluid intake;

- Programmed micturition;

- Verifying medicines used, like in cases of SAH and DM.

Source: thematic workshop n. 3 (2014).

\section{Table 1 - Possible orientations in primary health care}

As a result, for the sake of clear orientations, in easy language understandable to the elderly population, during this thematic workshop, all participants contributed in the elaboration of a folder to facilitate the communication between professional and elderly woman with UI, as presented in Figure 2 


\section{URINARY LOSS: WHAT TO DO?}

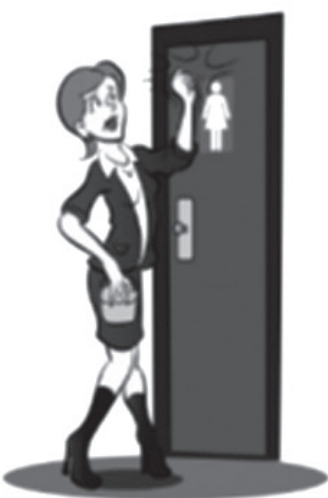

What is urinary incontinence?

$\checkmark$ Is any involuntary urine loss.
WHAT ARE THE SYMPTOMS?

STRESS URINARY INCONTINENCE

$\checkmark$ Do you lose urine while coughine. sneezing or laughing?

Sometimes, when you get up from a chair or the bed, do you lose urine?

$\checkmark$ Do you sleep well at night but get up more than twice to go to the bedroom?

$\checkmark$ Do you avoid exercising because you lose urine?

$\checkmark$ Do you not go to friends' house because you are afraid that the urine will smell?

URGE URINARY INCONTINENCE

Do you lose urine if you do not go to the bathroom quickly?

$\checkmark$ Do you need to visit the bathroom several times per day?

$\checkmark$ Do you feel a great urge to wee but the quantity that comes out when you reach the bathroom is small?

$\checkmark$ Do you not drink much because you are afraid of losing more urine?

\section{RISK FACTORS THAT CAN LEAD}

TO URINE LOSS:

- MANY PREgNANCIES/DEUUERIES

- GYNECOLOGICAL SURGICAL PROCEDURES

$\checkmark$ CUMACTERIUM/MENOPAUSE

$\checkmark$ HORMONE REPLACEMENT

$\checkmark$ OBestr

$\checkmark$ ALCOHOL/SMOKING

$\checkmark$ SEDENTARINESS

$\checkmark$ ChRONIC ILUNESSES

$\checkmark$ INTESTINAL CONSTIPATION

\section{ORIENTATIONS}

\& Empty the bladder completely when weeing:

\& Urinate calmly:

\& Do not hold the urine for lone:

\& Exercise regularly:

\& Eat healthily.

\& Avoid alcoholic beverage:

\& If possible, stop smoking:

* Avoid high-impact activity; $\phi$ If you 80 to the bathroom often, try to proeram vour micturition:

\& Be careful with the use of foods that irritate the bladder: products with caffeine, sparkline drinks, teas (diuretics), citric or acid fruits, chocolate drinks, vinegar, sweeteners, amone others

\section{CORREC MICTURIONON POSTION}

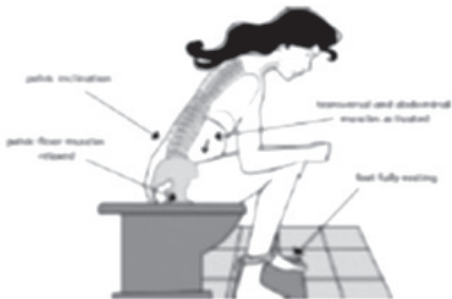

STRENGIENANG OXERES

1. Le down, breathe in and exhale while contracting the perineum as if you were holding your urine.

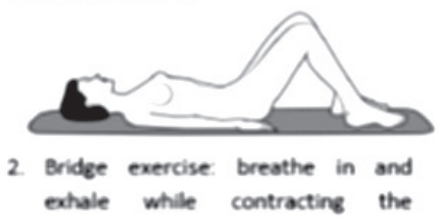
contraction exercise
4 While standine holdine a chair or table, do the same perineal

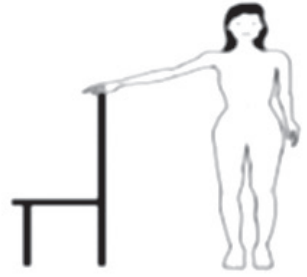

3. While sittine on the floor or the ball, with your back straicht and your feet restine breathe in and exhale while contractine the perineum as if you were holdine your urine

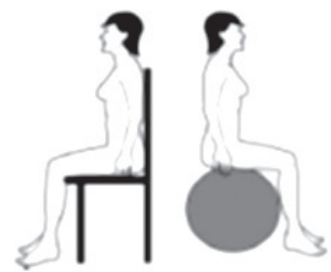

AT THE NENREST HEALT SERVIC AND TALX ABOUT YOUR URane Loss !

Elaborated by the researchers Andrelise V. R. Tomasi; and Dr. Silva M. A dos Santos; in cooperation with the participants in the $3^{\prime \prime}$ Thematic Workshop.

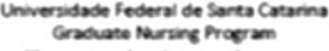

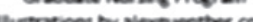

Source: thematic workshop n. 3 (2014).

Figure 2-Folder elaborated to help with information about urinary incontinence for the elderly population 
According to the professional who participated in the thematic workshops, this theoretical and practical knowledge contributed positively to strengthen and add new information with a view to the approach and correct orientations for patients on UI. This theme is not frequently discussed in the undergraduate program, and was therefore considered as new learning. Hence, it seems that these professionals could be sensitized to the importance of a multiprofessional approach for UI intervention.

This reflection supports another study aimed at educative actions on the teaching-learning processes, with a view to self-care training and the empowerment of elderly people. It was verified that the health professionals are the facilitators of individuals and communities' self-care practices. The challenge is to build strategies to facilitate that knowledge. In conclusion, reflection facilitates the learning process, with a view to overcoming the elements that limit a certain type of health care. ${ }^{32}$

In that sense, based on the thematic workshops, the professionals also highlighted the possibility to provide orientations more easily, after the reflections, being able to better identify those patients who can be monitored in PHC only, without the need for more specialized or surgical care.

We believe that, through these thematic workshops, we were able to reach the study objective as, in view of the discourse and comments uttered, the physiotherapists and nurses were sensitized to the theme and reflected on a distinguished care plan for elderly women with UI.

\section{CONCLUSION}

In this study, the importance of training on the theme UI was highlighted in PHC. This contributes to the appropriate diagnosis and treatment by the professionals. The implementation of care in elderly women with UI can now be considered a care possibility but, for that purpose, the professionals should be wiling to cope with the challenges of aging and the demands of the patients they attend.

In that context, all health professionals should be prepared, as PHC is the entry door to the Unified Health System. That is the level where strategies can be employed to develop actions related to the UI symptoms, with a view to minimizing the complications and health damage.

These results indicate that the physiotherapists and nurses' actions were somewhat limited, with activities that entailed no repercussions for the self-care of elderly women with UI. These pro- fessionals should be able to implement care for the women to incorporate their own health, including care related to UI symptoms.

In that sense, we hope that the reflection process about UI during this study has contributed to improve these professionals' care to prevent the disease, promote health and reduce problems.

In addition, new studies are suggested, involving other health professionals to establish more effective multiprofessional population, which has that many particularities.

Finally, we believe that, based on these study results, further investments are needed in the training of PHC professionals with a view to a more comprehensive approach to elderly health, promoting improvements in the wellbeing and quality of life.

\section{REFERENCES}

1. Tamanini JTN, Lebrão ML, Duarte YAO, Santos JLF, Laurenti R. Analysis of the prevalence of and factors associated with urinary incontinence among elderly people in the Municipality of São Paulo, Brazil: SABE study (health, wellbeing and aging). Cad Saúde Pública. 2009 Aug; 25(8):1756-62.

2. Santos CRS, Santos VLCG. Prevalência da incontinência urinária em amostra randomizada da população urbana de Pouso Alegre, Minas Gerais, Brasil. Rev Latino-Am. Enfermagem [Internet]. 2010 Set-Out [cited 2015 Jun 10]; 18(5):. Available from:http:// www.scielo.br/pdf/rlae/v18n5/pt_10.pdf

3. Rosa LHT, Souza CM, Lima CHL, Boggio ESB, Santos FC, Carboni C, et al. Prevalência da incontinência urinária em idosos de Porto Alegre-RS. Rev Geriatr Gerontol. 2014 Jul-Set; 9(2):112-17.

4. Rios AAN, Cardoso JR, Rodrigues MAF, Almeida SHM. The help-seeking by women with urinary incontinence in Brazil. Int Urogynecol J. 2011; 22:879-84.

5. Honório MO, Santos SMA. Incontinência urinária e envelhecimento: impacto no cotidiano e na qualidade de vida. Rev Bras Enferm. 2009; 62(1):51-6.

6. Busato WFSJ, Mendes FM. Incontinência urinária entre idosos institucionalizados: relação com mobilidade e função cognitiva. Arquivos Catarinenses de Medicina. 2007; 36(4):49-55.

7. Higa R, Lopes MHBM, Turato ER. Fatores de risco para incontinência urinária na mulher. Rev Esc Enferm USP. 2008 Mar; 42(1):187-92.

8. Mourão FAG, Lopes LN, Vasconcellos NPC, Almeida MBA. Prevalência de queixas urinárias e o impacto destas na qualidade de vida de mulheres integrantes de grupos de atividade física. Acta Fisiatr. 2008; 15(3):170-75.

9. Menezes MAJ, Hashimoto SY, Santos VLCG. Prevalence of urinary incontinence in a community 
sample from the city of São Paulo. Wound Ostomy Continence Nurs. 2009; 36(4):432-40.

10. Gomes GV, Silva GD. Incontinência urinária de esforço em mulheres pertencentes ao Programa de Saúde da Família de Dourados (MS). Rev Assoc Med Bras. 2010; 56(6):649-54.

11. Zhu L, LangJ,Liu C,XuT, LiuX, LiL,etal.Epidemiological study of urge urinary incontinence and risk factors in China. Int Urogynecol J. 2010; 21:589-93.

12. Gözükara F, Koruk I, Kara B. Urinary incontinence among women registered with a family health center in the Southeastern Anatolia Region and the factors affecting its prevalence. Turk J Med Sci. 2015; 45(4):931-9.

13. Berlezi EM, Fiorin AAM, Bilibio PVF, Kirchner RM, Oliveira KR. Estudo da incontinência urinária em mulheres climatéricas usuárias e não usuárias de medicação anti-hipertensiva. Rev Bras Geriatr Gerontol. 2011; 14(3):415-23.

14. Sacomori C, Negri NB, Cardoso FL. Incontinência urinária em mulheres que buscam exame preventivo de câncer de colo uterino: fatores sociodemográficos e comportamentais. Cad Saúde Pública. 2013 Jun; 29(6):1251-59.

15. Bolina AF, Dias FA, Santos NMF, Darlene MST. Incontinência urinária autorreferida em idosos e seus fatores associados. Rev Rene. 2013; 14(2):354-63.

16. Trentini M. O processo convergente-assistencial. In: Trentini M, Paim L, Silva DMGV. Pesquisa Convergente-Assistencial: delineamento provocador de mudanças nas práticas de saúde. $3^{\mathrm{a}}$ ed. Porto Alegre (RS): Moriá; 2014.

17. Ministério da Saúde (BR). Política Nacional de Promoção da Saúde. $3^{a}$ ed. Brasília (DF): Ministério da Saúde, 2010.

18. Ministério da Saúde (BR). Resolução No 466, de 12 de dezembro de 2012. Conselho Nacional de Saúde. Brasília (DF): Ministério da Saúde, 2013.

19. Elenskaia K, Haidvogel K, Heidinger C, Doerfl D, Umek W, Hanzal E. The greatest taboo: urinary incontinence as a source of shame and embarrassment. Wien Klin Wochenschr. 2011 May; 123:607-10.

20. Wang Y, Hu H, Xu K, Zhang X, Wang X, Na Y, Kang X, et al. Prevalence, risk factors, and symptom bother of nocturia: a population based survey in China. World J Urol., sep., 2014.

21. Borba AMS, Lelis MSA, Brêtas ACP. Significado de ter incontinência urinária e ser incontinente na visão das mulheres. Texto Contexto Enferm. 2008; 17(3):527-35.

22. Lopes MHBM, Higa R. Restrições causadas pela incontinência urinária à vida da mulher. Rev Esc Enferm USP. 2006; 40(1):34-41.

23. Luo X, Chuang CC, Yang E, Zou KH, Araiza AL, Bhagnani T. Prevalence, management and outcomes of medically complex vulnerable elderly patients with urinary incontinence in the United States. Int J Clin Pract [Internet]. 2015; [cited 2015 Nov 29]. Available from: http://onlinelibrary.wiley.com/doi/10.1111/ ijcp.12740/epdf

24. Wójtowicz U, Plaszwska-Zywko L, StangelWójcikiewicz K, Basta A. Barriers in entering treatment among women with urinary incontinence. Ginekol Pol. 2014; 85:342-7.

25. Pakgohar M, Sabetghadam S, Rahimparvar SFV, Kazemnejad A. Quality of life (QoL) and helpseeking in postmenopausal women with urinary incontinence (UI): a population based study. Archives of Gerontology and Geriatrics. 2014; 59:403-7.

26. Barbosa SS, Oliveira LDR, Lima JLDA, Carvalho GM, Lopes MHBM. Como profissionais de saúde da rede básica identificam e trata a incontinência urinária feminina. O Mundo da Saúde. 2009; 33(4):449-56.

27. Figueiredo EM, Baracho SM, Vaz CT, Sampaio RF. Educação de funcionárias de unidade básica de saúde acerca da atenção fisioterapêutica na incontinência urinária: relato de experiência. Fisioter Pesq. 2012; 19(2):103-8.

28. Loureiro LSN, Medeiros ACT, Fernandes MGM, Nóbrega MML. Incontinência urinária em mulheres idosas: determinantes, consequências e diagnósticos de enfermagem. Rev Rene. 2011; 12(2):417-23.

29. Glisoi SFN, Girelli P. Importância da fisioterapia na conscientização e aprendizagem da contração da musculatura do assoalho pélvico em mulheres com incontinência urinária. Rev Bras Clin Med. 2011 NovDez; 9(6):408-13.

30. Zanetti MRD, Castro RA, Rotta AL, Santos, PD, Sartori M, Girão MJBC. Impact of supervised physiotjerapeutic pelvic floor exercises for treating female stress urinary incontinence. São Paulo Med J. 2007; 125(5):265-69.

31. Sousa JG, Ferreira VR, Oliveira RJ, Cestari CE. Avaliação da força muscular do assoalho pélvico em idosas com incontinência urinária. Fisioter Mov. 2011 Jan-Mar; 24(1):39-46.

32. Gomes SS, Moya JLM. La interacción entre la perspectiva epistemológica de las enfermeras educadoras y los participantes (en programas educativos): límites y oportunidades en el desarrollo del empoderamiento para el fomento del autocuidado en salud. Texto Contexto Enferm. 2015; 24(2):301-9. 